Vol. 4, No. 2, 2019

\title{
ACTIVATOR OF CARBON DIOXIDE ABSORPTION BY CHLOROPHYLL-SYNTHESIZING MICROALGAE
}

\author{
Vasil Dyachok, Solomiia Mandryk, Serhiy Huhlych
}

\author{
Lviv Polytechnic National University, \\ Department of Ecology and Balanced Use of Natural Resources, \\ 12, S. Bandery Str., Lviv ,79013, Ukraine \\ dyachokvasil@gmail.com,solomiia.mandryk@ukr.net, zvit.reagent@gmail.com
}

https://doi.org/10.23939/ep2019.02.063

Received: 06.03.2019

(C) Dyachok V., Mandryk S., Huhlych S., 2019

\begin{abstract}
The influence of nitrogen oxides on the $\mathrm{CO}_{2}$ uptake rate by chlorophyll-producing microalgae of Chlorella type was investigated. Experimental dependences of microalgae concentration growth over time under certain values of nitrogen oxides concentration in the culture medium were obtained. The mathematical model of microalgae biomass growth depending on nitrogen oxides concentration was developed. Based on the solution of the mathematical model and the obtained experimental data, the concentration of nitrogen oxides for the maximal microalgae growth was determined.
\end{abstract}

Key words: nitrogen oxides $\left(\mathrm{N}_{\mathrm{x}} \mathrm{O}_{\mathrm{y}}\right)$, chlorophyllsynthesizing microalgae, biomass growth, mathematical model, optimum concentration.

\section{Introduction}

Nowadays, climate change on the Earth makes the world scientific community and world leaders of the states worry. The stimulus to attract attention was the rapid rise in temperature, which caused melting of glaciers, one of the consequences of which is the rise of the level of the world's ocean, and eventually catastrophic effects on a global scale.

One of the ways to solve this problem is to reduce the concentration of $\mathrm{CO}_{2}$ in the atmosphere by incorporating the photosynthetic properties of plant organisms in industrial environments. This is one of the methods of biological purification, which is based on the ability of chlorophyll-synthesizing microalgae to involve to the metabolism schemes the substances that cause environmental pollution, using them for nutrition in the process of their life. Unlike other green plants, microalgae have a number of significant benefits. They grow 7-8 times faster, and, accordingly, absorb larger concentrations of carbon oxide. This fact makes it expedient to consider the bases of the processes of purification of industrial gas emissions with the use of unicellular chlorophyllsynthesizing microalgae [1].

In the case of fuel combustion, in addition to carbon dioxide $\left(\mathrm{CO}_{2}\right)$ and sulfur $\left(\mathrm{SO}_{2}\right)$, a large amount of nitrogen oxides $\left(\mathrm{N}_{\mathrm{x}} \mathrm{O}_{\mathrm{y}}\right)$ is formed, which is subsequently oxidized to $\mathrm{NO}_{2}$ by the air. When it comes to the purification of industrial gas emissions with chlorophyllsynthesizing microalgae, it is important to determine the effect of nitrogen oxides on the processes of carbon dioxide absorption by microalgae.

Among the known methods, biological purification has a number of significant advantages, thanks to the remarkable ability of microorganisms to adapt to extremely unfavorable conditions: in particular, at high concentrations of a mixture of pollutants, etc., which makes this method the most effective and safe [2]. Therefore, the establishment of threshold concentrations of toxicants, primarily in photo-biorreactors, which undergo processes for the absorption of greenhouse gases by microalgae under industrial conditions, is an urgent need nowadays.

There is little data on the effect of nitrogen oxide $\left(\mathrm{N}_{\mathrm{x}} \mathrm{O}_{\mathrm{y}}\right)$ on the growth rate of microalgal biomass. Therefore, it is important to study the effect of nitrogen oxide on the activity of microalgae.

The goal of the work is to study the effect of nitrogen oxides on the rate of absorption of carbon dioxide chlorophyll-synthesizing microalgae of the Chlorella type in the aquatic habitat. 


\section{Theoretical part}

The basis of the processes of mass transfer of cells with the environment is a complex sequence of biochemical reactions organized in a certain way in time and space, the result of which is a change in the concentration of the substance, the number of individual cells, and the biomass of microorganisms, etc.

The photosynthetic processes combine biological, chemical and physical mechanisms. As a rule, the most promising and user-friendly have always been the technologies that combine three elements physical, chemical and biological. The technology built on this principle gives mankind the necessary final product with minimal cost of production and minimal emissions to the environment. Such technology can be created only by studying in detail how it proceeds in a single cell.

Investigation of the biochemistry of the process of photosynthesis in different organisms (bacteria, microalgae, higher plants) showed that along with the diversity of phenomena there is a single biochemistry of the process described by the reaction:

$$
\mathrm{DH}_{2}+\mathrm{A}+\boldsymbol{h v} \rightarrow \mathrm{AH}_{2}+\mathrm{D}
$$

where $\boldsymbol{D H} \boldsymbol{H}_{2}$ is a donor of hydrogen atoms $\left(\mathrm{H}_{2} \mathrm{O} ; \mathrm{H}_{2} \mathrm{~S}\right)$; $A$ is their acceptor, $\left(\mathrm{CO}_{2} ; \mathrm{NO}^{-3}\right)$.

In addition, the general feature of the process of photosynthesis is also the formation of adenosine triphosphoric acid (ATP).

The study of the regularities of the primary photosynthetic processes of algae is of great practical importance, since it will provide an increase in the productivity of valuable in economic terms, not traditional types of mobile microalgae. The use of a fast, cheap and simultaneously reliable method for controlling the physiological state of mobile representatives of microscopic algae is necessary for controlling their productivity under conditions of industrial photosynthesis.

The simplest link in the chain of nutrients of microalgae is carbon dioxide $\left(\mathrm{CO}_{2}\right)$, water and other nutrients that, as a result of photosynthesis, transform into organic matter. Since there is a certain amount of nutrients in the culture medium, the microalgae grow, as long as the content of any component they need does not reach a critical value, after which the growth is slowed down.

Analyzing the composition of phytoplankton, scientists have investigated that carbon, nitrogen and phosphorus are the most important and their atomic ratio is $108: 16: 1$. Thus, based on one atom of phosphorus (usually present in the form of hydrophosphate ion $\mathrm{HPO}_{4}{ }^{-2}$ ) and 16 nitrogen atoms (usually in the form of a nitrate-ion $\mathrm{NO}_{3}^{-}$) 108 molecules of $\mathrm{CO}_{2}$ are needed. These are the most important components of the process of photosynthesis [3].

Therefore, the regulation of microalgal cultivation conditions in the presence of toxicants is a prerequisite for achieving high productivity of microalgal culture, in industrial volumes, which will provide a high degree of purification of gas emissions.

For the research a culture of green microalgae of the Chlorella type was chosen (Fig. 1). Microscopic chlorophyll-synthesizing microalgae of the Chlorella type are unpretentious to living conditions and capable of intensive reproduction, and therefore occur everywhere: in fresh water, seas and soils.

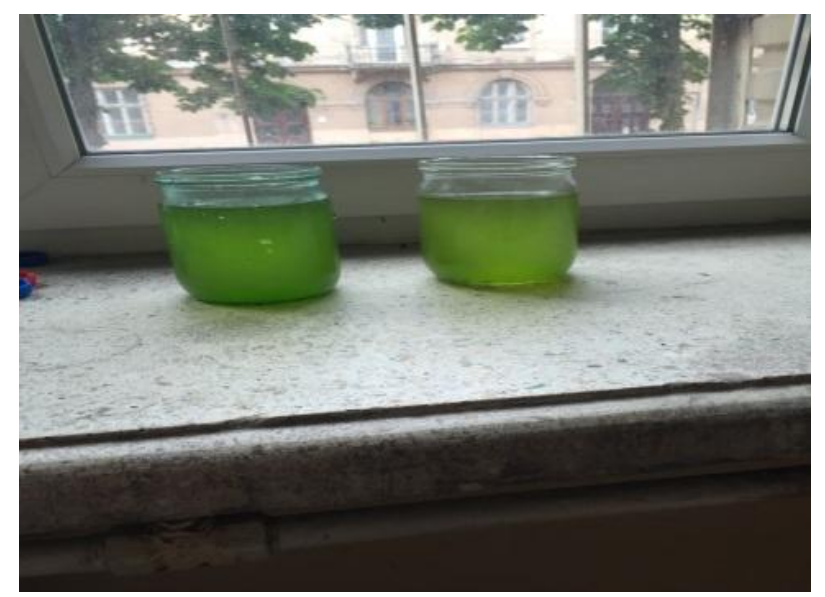

Fig. 1. Microalgae of the Chlorella type

From literary sources it is known that the concentration of nitrogen oxides that adversely affects the flora is within the range of $0.17-0.35 \mathrm{mg} / \mathrm{m}^{3}$ [4]. Therefore, it was important to investigate the concentration of harmful effects on microalgae of the Chlorella type and, therefore, research within these concentrations was the impetus for our work. 


\section{Presentation of the main material and discussion of the results}

The object of the laboratory research was Chlorella the culture of green microalgae. For this purpose water was taken from the pond where the standard nutrient medium was introduced, and a culture of microalgae Chlorella was added. Cultivation was has been carried out for 11 days in six phyto-bioreactors with the volume of 1liter. Nutrients - carbon dioxide and mineral nutrition elements of the microalgae cells were obtained directly from the environment by bubbling, absorbing them with their entire surface. Since nitrogen dioxide is absorbed by micro-algae in the form of anion $\mathrm{NO}_{\mathrm{a}}^{-}$, for the study of the effect of nitrogen oxides on the growth of chlorophyll-synthesizing microalgae, an anion with the concentration of $1.7 \mathrm{mg} / \mathrm{m}^{3}$ was added to the first volume, $3.4 \mathrm{mg} / \mathrm{m}^{3}$ - to the second, $8,5 \mathrm{mg} / \mathrm{m}^{3}$ - to the third, $15.6 \mathrm{mg} / \mathrm{m}^{3}$ - to the fourth, $34 \mathrm{mg} / \mathrm{m}^{3}$ to the fifth, and $68 \mathrm{mg} / \mathrm{m}^{3}$ to the sixth one.

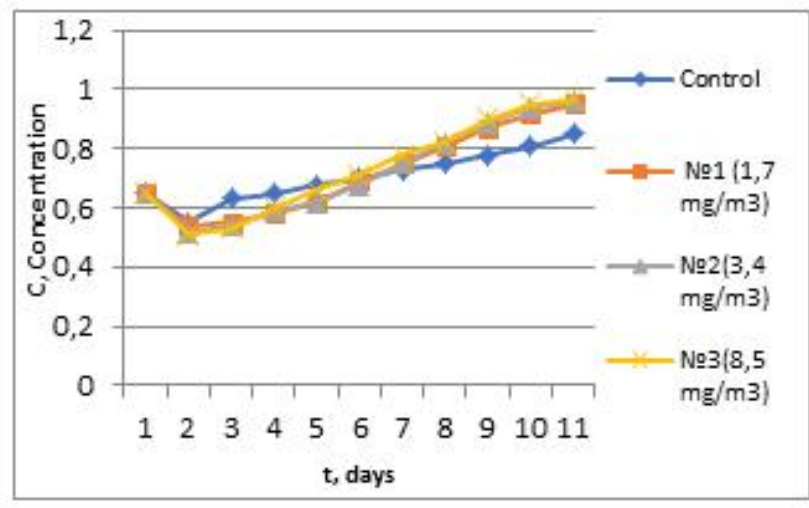

Fig. 2.1. Dependence of the change in the concentration of cells of algae in time at appropriate concentrations $\mathrm{NO}_{3}^{-}$

Analyzing the data (Fig. 2.1, Fig. 2.2), it should be noted that the increase in the concentration of microalgae cells significantly depends on the concentration of nitrogen oxides $\left(\mathrm{N}_{\mathrm{x}} \mathrm{O}_{\mathrm{y}}\right)$ compared with the control, which did not contain oxides of nitrogen. Under such conditions, the growth of microalgae in a liquid medium that is well stirred varies over time, depending on the concentration of nitrogen oxides.

As the concentration of nitrogen oxides increases (NxOy), the growth of the algae cells increases, but to a certain value. As shown in (Fig. 2.2) the sixth test on the second day behaves in the same way as others, that is, it also adapts, and from the third day the growth begins, which even on the fifth day is higher than in the control sample, but from the sixth day there is a decline and in the next five days neither growth nor death of microalgae is observed. A similar dynamics, but with a
The growth of biomass chlorophyll-synthesizing microalgae under these conditions was determined by a photo-colorimetric method using a blue light filter according to Bouguer-Lambert-Ber.

Since the optical density is proportional to the concentration of algae, which is confirmed by the calibration graph, therefore the experimental data on the accumulation of algae biomass depending on the time within the studied nitrogen oxide concentration $\left(\mathrm{N}_{\mathrm{x}} \mathrm{O}_{\mathrm{y}}\right)$ correspond to the value of optical densities [5].

By the change in the concentration of cells (number of cells per unit volume of suspension) or the density of microorganisms (dry weight of microorganisms per volume unit of suspension) the rate of growth of microalgae was determined. Based on the results of experimental data and calculation values, graphically dependent changes in the concentration of algae cells in time at the appropriate concentrations of nitrogen oxides $\left(\mathrm{N}_{\mathrm{x}} \mathrm{O}_{\mathrm{y}}\right)$ in a solution under the conditions of their single injection were obtained (Fig. 2.1, Fig. 2.2).

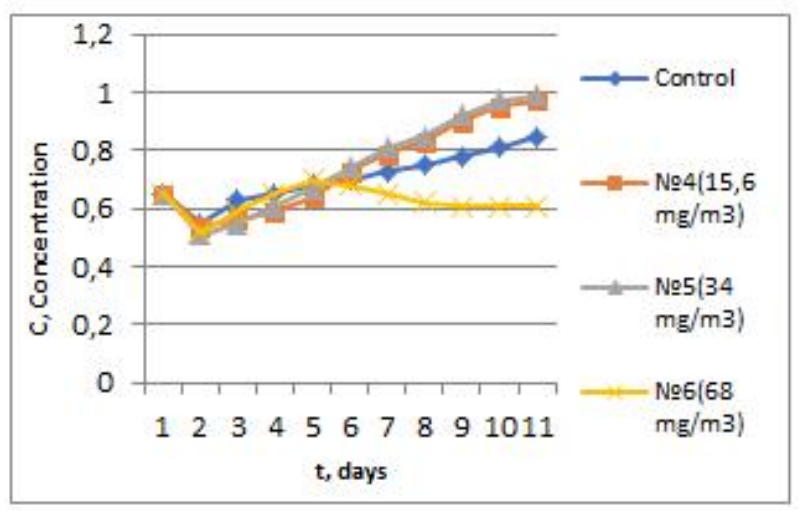

Fig. 2.2. Dependence of the change in the concentration of cells of algae in time at appropriate concentrations $\mathrm{NO}_{\mathrm{n}}^{-}$

lower concentration, is also observed in a control tank that has not been exposed to nitrogen oxides ( $\mathrm{NxOy}$ ).

The main parameter characterizing the growth of microalgae $\Delta k$ is a specific growth rate:

$$
\Delta k=\Delta C / C \times \Delta T,
$$

where $\Delta C$ is the increase in the concentration of microalgae, $C$ is the concentration of microalgae, $\Delta k$ is specific growth rate or coefficient of growth rate $\left(\mathrm{c}^{-1}\right)$.

On the other hand, the coefficient of growth can be determined from the equation [6]:

$$
d C / d t=k \times C \text {. }
$$

According to this equation, the growth factor characterizes the relative increase in the density of algae per time unit. If for some time $\Delta k$ remains unchanged, then such increase is called exponential, and the corresponding time interval is the exponential growth phase [7]. 
Integrating the equation (3), and defining permanent integration, provided that at the initial time $\mathrm{t}=0$ the initial concentration of the cells of algae is $\mathrm{C}_{0}$, we obtain:

$$
C=C_{0} \times \exp (k t)
$$

Since the logarithmic dependence of the concentration of microalgae cells on the time in the

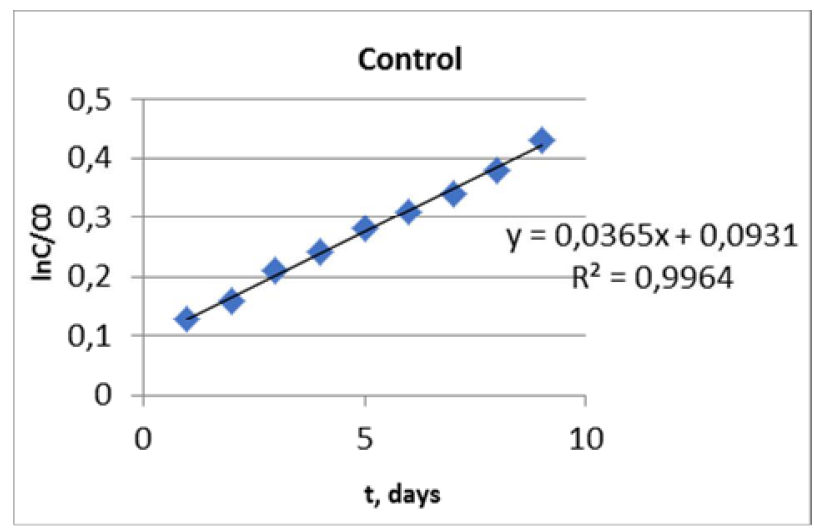

Fig. 3.1. Dependence of change in the logarithm of concentration of suspension of microalgae cells from time (control)

The obtained dependences allow us to determine the growth factor $\mathrm{k}$ as the tangent of the angle of inclination of the experimental lines, which are: for the control line $-0.036 \mathrm{c}^{-1}$; at a concentration of $1.7 \mathrm{mg} / \mathrm{m}^{3}-0.075 \mathrm{c}^{-1}$; at a concentration of $3.4 \mathrm{mg} / \mathrm{m}^{3}-0.076 \mathrm{c}^{-1}$; at a concentration of $8.5 \mathrm{mg} / \mathrm{m}^{3}-0.0777 \mathrm{c}^{-1}$; at a concentration of $15.6 \mathrm{mg} / \mathrm{m}^{3}-0.078 \mathrm{c}^{-1}$; at a concentration of $34 \mathrm{mg} / \mathrm{m}^{3}-0.0779 \mathrm{c}^{-1}$; at a concentration of $68 \mathrm{mg} / \mathrm{m}^{3}-0.037 \mathrm{c}^{-1}$. Since in samples $1-5$ there is an increase in the growth of microalgal biomass, the value of the growth coefficient is positive. In the case of the sixth sample, there is a decrease in the growth of microalgae, so the value of the growth coefficient $k$ is negative.

The mathematical formulation of the growth model for the biomass of algae under the condition of the increase in the concentration of nitrogen oxides is the system of equations [8]:

$$
\left\{\begin{array}{l}
\frac{d C}{d x}=k_{1} C-k_{2} C \\
\frac{d C}{d \mathrm{x}}=k_{1} C ; \\
x=0, C=C_{o},
\end{array}\right.
$$

where $x$ is the concentration of oxides nitrogen; $k_{1}, k_{2}$ are the coefficients of growth for favorable (activation) and unfavorable (inhibition) values of the concentration of nitrogen oxides; period of exponential growth is a linear dependence, this makes it possible to determine the growth factor $k$ as the tangent of the angle of inclination of the straight line. Therefore, substituting the experimental data in equation (4), we have the dependences $\ln C=\mathrm{f}(t)$, which are shown in (Fig. 3.1, Fig. 3.2).

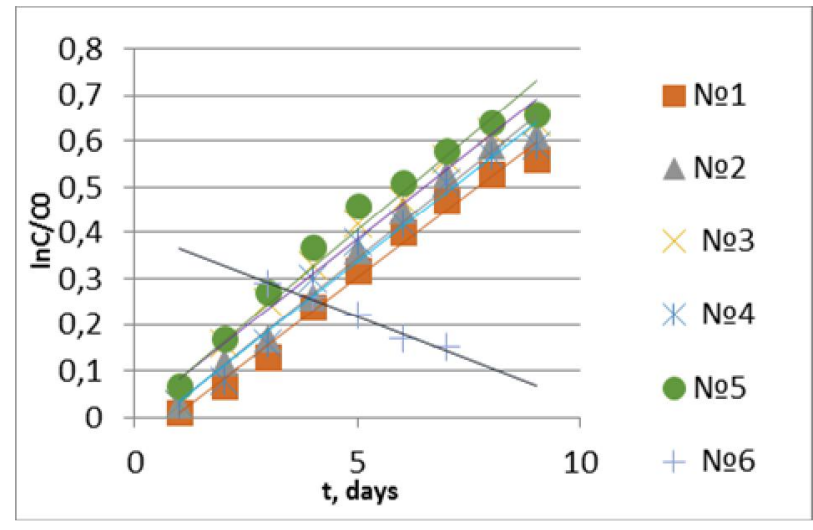

Fig. 3. 2. Dependence of change in the logarithm of concentration of suspension of microalgae cells from time (at appropriate concentrations $\mathrm{NO}_{3}^{-}$)

$C$ is the concentration of microalgae in the suspension.

The solution of a mathematical model is the equation that allows determining the concentration to achieve the maximum growth of microalgae;

$$
x_{\text {max }}=\frac{\ln k_{2}-\ln k_{1}}{\left(k_{1}+k_{2}\right)} .
$$

Using the data of mathematical processing of the results of experimental studies of the population growth, the corresponding values of the coefficients of growth $k_{1}$ and $k_{2}$ were calculated. After substituting the obtained values into equation (6), the optimum concentration of nitrogen oxides in the culture medium was calculated.

$$
\begin{gathered}
x_{\max }=\frac{\ln k_{2}-\ln k_{1}}{\left(k_{1}+k_{2}\right)} ; \\
=\frac{\ln (-0.037-\ln 0.076}{(0.076-0.037)}=18.46 \mathrm{mg} / \mathrm{m}^{3} .
\end{gathered}
$$

This is the concentration of nitrogen oxides $\left(\mathrm{N}_{\mathrm{x}} \mathrm{O}_{\mathrm{y}}\right)$ in which the maximum concentration of biomass of algae in the cultivation environment is reached. To verify the adequacy of the mathematical model and its solution, a graph of dependency of the growth of the concentration of microalgae on the concentration of nitrogen oxides $\left(\mathrm{N}_{\mathrm{x}} \mathrm{O}_{\mathrm{y}}\right)$ was constructed on the basis of experimental data. 




Fig. 4. Dependence of the growth

of the microalgae concentration on the concentration of $\mathrm{N}_{\mathrm{x}} \mathrm{O}_{\mathrm{y}}$.

From (Fig. 4), it is evident that the maximum increase in the concentration of microalgae is achieved at the concentration of $\mathrm{N}_{\mathrm{x}} \mathrm{O}_{\mathrm{y}} \approx 18 \mathrm{mg} / \mathrm{m}^{3}$. This indicates that the mathematical model describes the course of the investigated process rather accurately, and the solutions allow predicting optimal parameters for the implementation of the technology of absorption of greenhouse gases, provided that nitrogen oxides $\left(\mathrm{N}_{\mathrm{x}} \mathrm{O}_{\mathrm{y}}\right)$ are present in them.

According to the results of mathematical processing of experimental data, the increase in the concentration of nitrogen oxides is proportional to the growth of the biomass growth rates, as shown in (Fig. 4), but to certain values. Achieving a certain critical concentration value $\left(\mathrm{N}_{\mathrm{x}} \mathrm{O}_{\mathrm{y}}\right)$ has a deleterious effect that is successfully displayed in (Fig. 4).

Having obtained the growth coefficient $\mathrm{k}$, a graph of dependency of $\mathrm{NxOy}$ concentration on the growth coefficient k. (Fig. 5).

\section{Conclusion}

The results of experimental studies on the growth of biomass of chlorophyll-synthesizing microalgae, based on the concentration of nitrogen oxides $\left(\mathrm{N}_{\mathrm{x}} \mathrm{O}_{\mathrm{y}}\right)$, are presented. The methodology for calculating the concentration of the Chlorella type microalgae in the solution is given, and the rate of the algae population growth, depending on the time, is determined. A mathematical model of the population growth of the Chlorella type microalgae, based on the concentration of nitrogen oxides, was constructed. Based on the solution

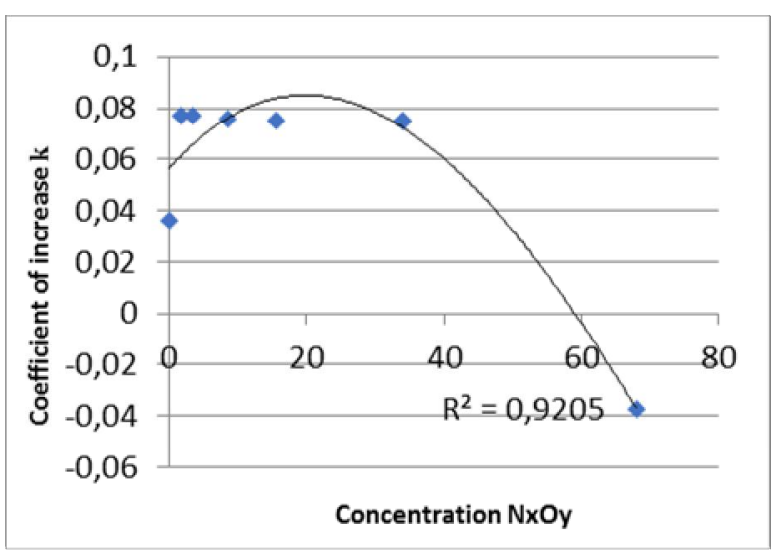

Fig. 5. Dependence of NxOy concentration on growth coefficient $\mathrm{k}$.

of the mathematical model and the experimental results obtained, the value of the optimum concentration of nitrogen oxides $\left(\mathrm{N}_{\mathrm{x}} \mathrm{O}_{\mathrm{y}}\right)$ for the growth of microalgae is calculated.

\section{References}

[1] Kolektuv avtoriv; za nayk. red M. S. Malovanyi: Rozvutok i vidtvorennya resyrsnogo potenzialy sybektiv ekologo-ekonomichnux, tyrustuchnux ta ekoinchormazinux sustem: monograchiyaю L.: Vudavnytstvo Lviv Polytechnic, 2015. 340 p.(in Ukrainian).

[2] V. V. Dyachok, S. I. Guglych, O. B. Levko. Vuvchennya vpluvy temparatyru na kinetuky poglunannya vyglekuslogo gazy microvodorostyamu// Visnuk National University "Lviv Polytechnic". Chimiya, technologiya rechovun ta ich zastosyvannya. 2015. No. 812. P. 365-372. (in Ukrainian)

[3] T. Braun translated from English by E. L. Rosenberg, M.: Chemistry at the Center for Science. Mir. 1983. 520 p.

[4] Goldovskaya L. F. Chimiya okryzauchei sredu: uchebnic dlya vyzov po spezialnosti Oxrana okryzauchei sredu i razionalne ispolzyvanie prurodnich resyrsov-3rd ed. M; M. 2008. 295 c. (in Russian)

[5] Dyachok V., Huhlych S., Yatchyshyn Y., Zaporochets Y., Katysheva V. About the problem of biological processes complicated by mass transfer // Chemistry \& Chemical Technology. 2017. T. 11, No. 1. S. 111-116.

[6] O. Stetsenko, R.P. Vinogradova. Bioorganichna chimiya K.: Vucha chkola, 1992. 278 s. (in Ukrainian)

[7] Gubsky Yu. I. Biologichna chimiya. K. - V .: Nova knuga, 2007. 137 p. (in Ukrainian)

[8] O. K. Zolotareva, E. I. Sniukova, O. O. Sivash, Perspektuvu vukorustannya microvodorostei y biotechnologii/ AlterPres, 2008. 234 p. (in Ukrainian) 